\title{
Wood characterization of Tectona grandis L. F. cultivated in Brazil: a review of the
}

\section{last 30 years}

\author{
Caracterização da madeira de Tectona grandis L. F. cultivada no Brasill: uma revisão dlos últimos 30
}

anos

Caracterización de la madera de Tectona grandis L. F. cultivada en Brasil: una revisión de los

últimos 30 años

Received: 10/08/2021 | Reviewed: 10/15/2021 | Accept: 10/26/2021| Published: 10/29/2021

\author{
Israel Luiz de Lima \\ ORCID: https://orcid.org/0000-0002-4868-6414 \\ Instituto de Pesquisas Ambientais, Brazil \\ E-mail: limailde@gmail.com \\ Maurício Ranzini \\ ORCID: https://orcid.org/0000-0001-8795-7013 \\ Instituto de Pesquisas Ambientais, Brazil \\ E-mail: ranzini@gmail.com \\ Eduardo Luiz Longui \\ ORCID: https://orcid.org/0000-0002-7610-9147 \\ Instituto de Pesquisas Ambientais, Brazil \\ E-mail: elongui@ @p.gov.br \\ Juraci de Andrade Barbosa \\ ORCID: https://orcid.org/0000-0002-8306-4514 \\ Instituto de Pesquisas Ambientais, Brazil \\ Universidade Federal de São Carlos, Brazil \\ E-mail: juraci_andrade@hotmail.com
}

\begin{abstract}
Worldwide, Tectona grandis (teak) is recognized for its productivity and the quality of its wood. The Brazilian market is already seen as a great potential for consumption and production of teak wood. Therefore, the objective of this work was to characterize the teak wood grown in Brazil through a bibliographic survey of the results already available. In general, it was found that the teak wood planted in Brazil has a certain variability in its technological properties, and these variations are due to the origin, genetic material, age, planting location and the cycle used in the management of the forest. In a way, we still do not have much research on the quality of teak wood, and it would be important to implement research programs and experiments that consider the different genetic materials, growing environments, planting spacing, silvicultural tracts and ages of cutting, to allow greater knowledge about the growth and the factors that can influence the quality of the wood to be produced.
\end{abstract}

Keywords: Teak; Wood quality; Wood anatomy; Wood density.

\section{Resumo}

Mundialmente, Tectona grandis (teca) é reconhecida pela sua produtividade e qualidade de sua madeira. O mercado brasileiro já é visto como um grande potencial de consumo e de produção de madeira de teca. Assim sendo, o objetivo desse trabalho foi caracterizar a madeira de teca cultivada no Brasil através de um levantamento bibliográfico dos resultados já disponibilizados. De maneira geral constatou-se que a madeira de teca plantada no Brasil apresenta uma certa variabilidade nas suas propriedades tecnológicas, sendo que essas variações são decorrentes da procedência, material genético, idade, local de plantio e o ciclo utilizado, no manejo da floresta. De certa forma, ainda não temos muitas pesquisas sobre a qualidade da madeira da teca, sendo que seria importante a implementação de programas de pesquisas e de experimentos que considerem os diferentes materiais genéticos, ambientes de crescimento, espaçamentos de plantio, tratos silviculturais e idades de corte, para permitir maior conhecimento sobre o crescimento e os fatores que podem influenciar na qualidade da madeira a ser produzida.

Palavras-chave: Teca; Qualidade da madeira; Anatômia da madeira; Densidade da madeira.

\section{Resumen}

A nivel mundial, Tectona grandis (teca) es reconocida por su productividad y la calidad de su madera. El mercado brasileño ya se ve como un gran potencial para el consumo y producción de madera de teca. Por tanto, el objetivo de este trabajo fue caracterizar la madera de teca cultivada en Brasil a través de un relevamiento bibliográfico de los 
resultados ya disponibles. En general, se encontró que la madera de teca plantada en Brasil tiene cierta variabilidad en sus propiedades tecnológicas, y estas variaciones se deben al origen, material genético, edad, lugar de plantación y ciclo utilizado en el manejo forestal. De alguna manera, todavía no tenemos mucha investigación sobre la calidad de la madera de teca, y sería importante implementar programas de investigación y experimentación que consideren los diferentes materiales genéticos, ambientes de cultivo, espaciamientos de plantación, tratamientos silvícolas y edades de corte, para Permitir un mayor conocimiento sobre el crecimiento y los factores que pueden influir en la calidad de la madera a producir.

Palabras clave: Teca; Calidad de la madera; Madera anatómica; Densidad de la madera.

\section{Introduction}

Currently, Tectona grandis L. F. (Lamiaceae), popularly known as teak, has stood out for the productivity and wood quality, being, therefore, another good option for wood sector. It is a native species of tropical forests located between $10^{\circ}$ and $25^{\circ} \mathrm{N}$ in the Indian subcontinent and in Southeast Asia, mainly in India, Burma, Thailand, Laos, Cambodia, Vietnam and Java. It has a high adaptability with vertical dispersion between 0 and 1,300 $\mathrm{m}$ above sea level, occurring in areas with annual precipitation of 800 to $2,500 \mathrm{~mm}$ and extreme temperatures from $2^{\circ}$ to $42^{\circ} \mathrm{C}$, but it does not resist frost. In Asia, its rotation cycle varies from 60 to 100 years (Lamprecht, 1990). The adaptive potential of teak to Brazilian climatic conditions has similarities to the adaptive potential of Khaya ivorensis (African mahogany), as both species require humid and hot tropical climates, with precipitation between 1,300 $\mathrm{mm}$ / year and 2,500 mm / year. Teak develops well and shows good growth, with a temperature between $13^{\circ} \mathrm{C}$ and $43^{\circ} \mathrm{C}$, in the dry season, with water availability below $50 \mathrm{~mm} /$ month (Figueiredo et. al., 2005). Thus, its adaptive capacity is an important alternative in terms of diversifying activities, as well as adding value to rural producers.

Globally, teak wood is recognized as being of excellent quality, valued for its beauty, strength and durability, and it can be used in the production of furniture, high-end frames, boats, decoration, shipbuilding, lamination and plywood, firewood and charcoal. It has great demand in the world market, reaching prices up to three times higher than those of mahogany, Swietenia macrophylla (Lamprecht, 1990; Lorenzi et al., 2003).

The Brazilian market is seen as a great potential for consumption and production of teak wood, and currently we have 93,957 ha planted with this species (IBÁ, 2019). However, producers still have many difficulties in commercializing teak, because national market is very restricted, one of the alternatives to improve commercialization would be the processing of wood on the farm, producing boards, furniture and doors, adding commercial value to the wood (Pires et. al., 2020).

The growing market interest in good quality teak wood has been reflected in the systematic increase in planted areas, as in the Midwest and North regions of Brazil (Figueiredo \& de Sá, 2015). In Figure 1, we have the evolution of the planted area in Brazil, between the years 2010 to 2018 (IBÁ, 2019). Teak planting is considered an economically viable alternative considering a 21-year cycle, the sensitivity analysis proved that this is a stable activity even with market changes, as it maintains productivity over the years. However, there are still many doubts about teak management (Figueiredo \& de Sá, 2015; Pires et. al. 2020). 
Figure 1. Area planted with Tectona grandis in Brazil between 2010 - 2018.

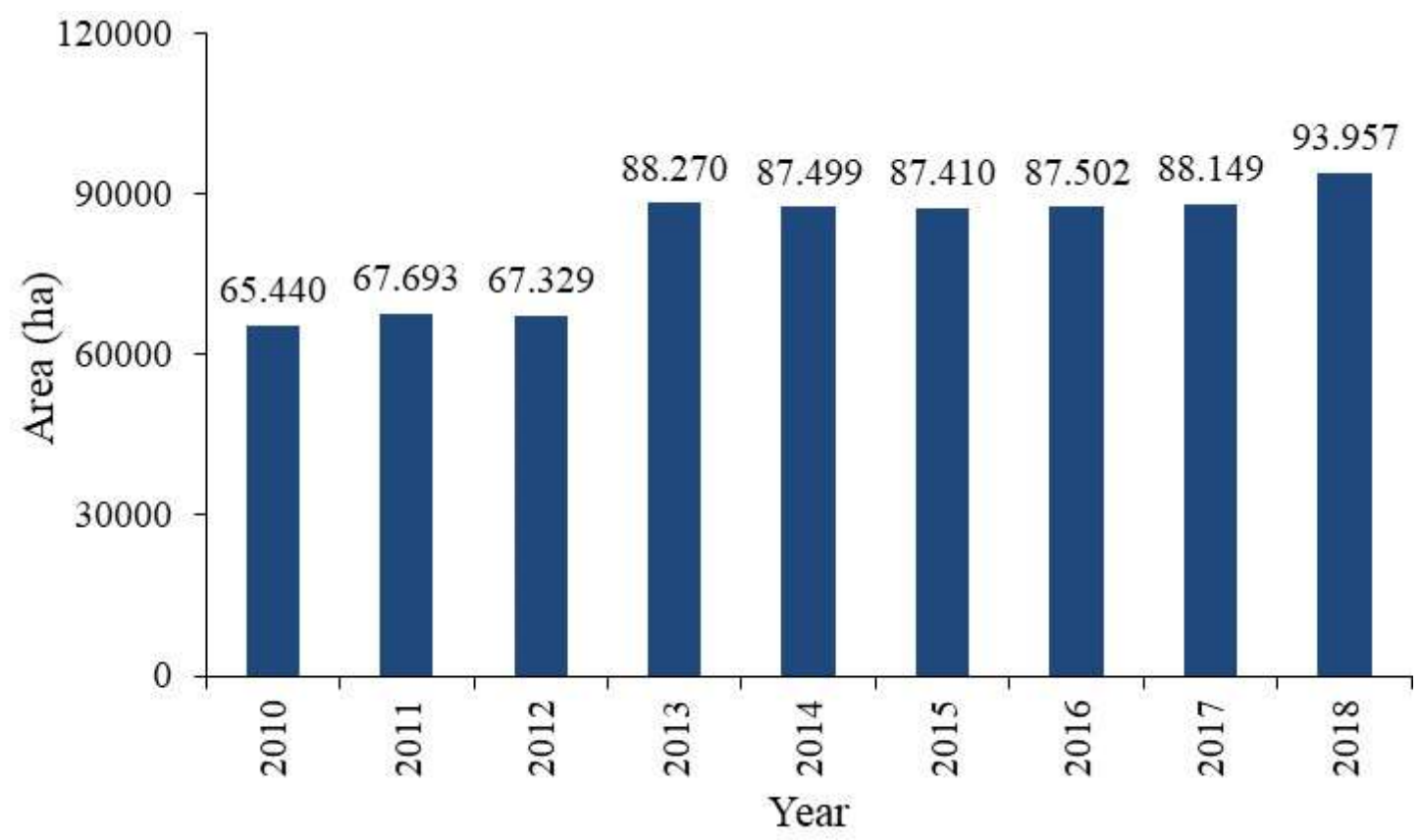

Source: adapted from (IBÁ, 2019).

\section{Methodology}

Our study is based on a bibliographical review on wood characterization of Tectona grandis (teak) cultivated in Brazil at last 30 years, between 1991 and 2021, carried out in different indexing bases. In addition to the relation and discussion of this information based on the experience of our team.

\section{Review of general properties of Tectona grandis wood}

\subsection{Heartwood and sapwood relationship}

Teak wood logs wood have a narrow, light sapwood of a yellowish color, quite distinct from the heartwood, whose color is bright and bright brown. The growth rings are clear and differentiated in the cross-sections (Figure 2).

Figure 2. Cross section of the Tectona grandis log.

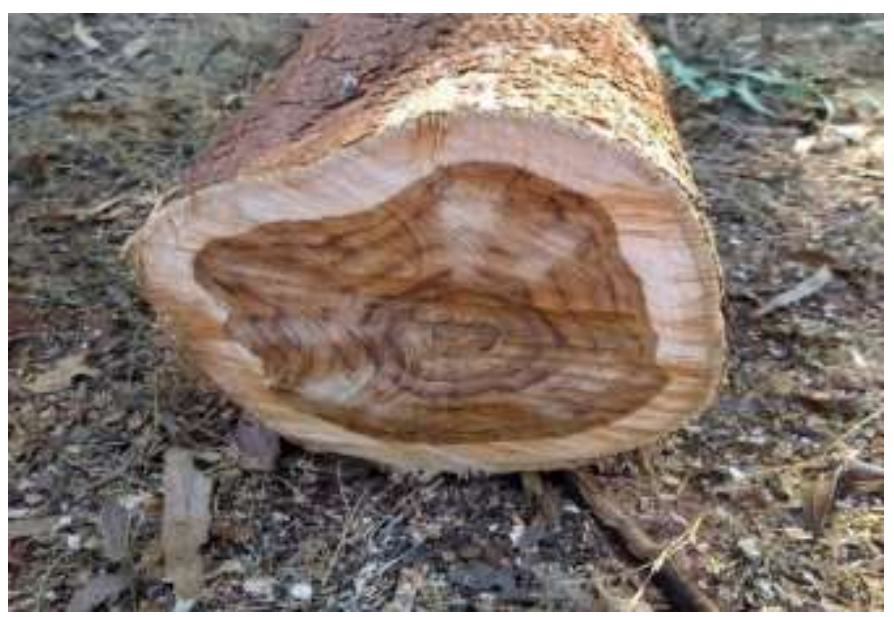

Source: https://www.mfrural.com.br/detalhe/313147/madeira-teca. 
The yields in the heartwood are about $77.84 \%$ in relation to total volume of log, this result is very important in economic terms, since commercial value of heartwood is higher than sapwood, as heartwood properties presents superior quality compared to sapwood (Pimentel et. al. 2008). Due to the higher relative percentage of heartwood in teak wood, it is more resistant to attacks by xylophagous agents when compared to the following species: Acacia mangium, Casuarina sp., Eucalyptus cloeziana, Corymbia torelliana (Paes et. al. 2016).

Wood has good resistance to attacks by fungi and insects, it also has high durability when subjected to weathering, the high percentage of heartwood results in this natural resistance to woody xylophagous agents, but it is susceptible to attacks by marine organisms (Lamprecht, 1990; Lorenzi et al., 2003).

Heartwood percentage of wood is influenced by tree age. Typically, at younger ages, this percentage is lower. However, silvicultural practices, local growth conditions and species origin can also influence heartwood percentage (Kokutse et al., 2004). The larger 7-year-old teak trees already have a higher relative percentage of heartwood than the smaller trees, nonetheless, the heartwood/sapwood ratio increased between the ages of 10 and 16 years old. (Benedetti, 2018, Canal et. al. 2020).

The wood has good natural resistance, with a loss of mass of $25.43 \%$. This good natural durability is due to tectoquinone, an extractive from flavonoid class, which is contained in wood cells, and the sapwood and heartwood have a substance called rubber, which reduces water absorption and, consequently, the development of xylophagous, fungi and this results in a moderate resistance to decay and high resistance to attacks of dry wood termites, however, in contact with the soil and moisture, the wood has a low durability. In this case, the use of prophylactic treatment is necessary (Corassa et al., 2013). In addition, it has high biological resistance to Gloeophyllum trabeum fungus causer of brown rot, both in the heartwood and sapwood regions. For Trametes versicolor fungus causer of white rot, sapwood was classified as having moderate biological resistance, while heartwood was classified as resistant (Oliveira et al., 2019).

The heartwood is characterized as highly resistant to subterranean termites Nasutitermes sp., however, sapwood does not present resistance (Motta et al., 2013). Wood from the first thinning that has heartwood and sapwood does not present many restrictions of use, being even advantageous, as the heartwood and sapwood, together, contrast, generating magnificent designs, but in the use, only of the sapwood region it is made treatment with waterproofing is necessary, since this region has an anisotropy coefficient in swelling, although normal, extremely close to what is considered a bad value, thus being susceptible to problems generated by humidity changes (Finger et. al. 2003). Wood treated with chemical products presents an increase in the wood density, due to preservative fixation in wood. In the preservative treatment of posts, retention of chromated copper arsenate preservative (CCA) is satisfactory for use of treated wood without direct contact with the soil or moisture as established by current Brazilian technical standards (Chagas et al., 2014).

\subsection{Ratio juvenile wood / adult wood}

Wood quality varies from tree to tree as well as within individual trunks. The variation in the radial direction is the most important source of variation, its extension being determined by the proportion of juvenile wood and its influence on the wood properties along the radius (Malan, 1995). Juvenile wood is formed by the cambium in the first years of tree trunk growth, and is located around the pith. This period of growth is called youth. In the logs of very young trees, almost all the wood is juvenile. However, in the older logs, there is juvenile wood only in very small portion of the trunk center. The juvenile period varies by species and can be affected by environmental factors. Adult wood is formed after the period of youth and, in general, wood cells reach their maximum dimensions and they remain more or less constant, except when they are drastically influenced by environmental conditions (Zobel, 1981; Câmara, et. al., 2020). 
The proportion of juvenile wood in a log is a characteristic that depends fundamentally on the tree age, as well as, on environment and management, however, at the same age and in similar conditions of environment and management, it can be verified that there is a great variability in this aspect to the point that the properties of juvenile and adult wood from the same tree differ significantly (Malan, 1995; Câmara et. al., 2020). The duration of the juvenile period varies according to each species and the environment, in a young tree this period can occupy about $85 \%$ of the trunk, and in an older tree the occupation reaches $10 \%$, this characteristic seems to be associated with the speed with which the transition from juvenile to adulthood occurs (Jankowsky, 1979; Câmara et. al., 2020).

The big difference in terms of juvenile wood compared to adult wood is in the magnitude of anatomical and physical changes that occur from the pith to the bark of the trunk. In general, according to the literature, for hardwood, which is the case of teak, some characteristics of juvenile wood are: shorter vessels and fibers, smaller cell diameter, thinner cell wall of fibers, higher fibrillar angles, higher proportion of fibers, lower proportion of vessels, higher relative content of hemicellulose, lower relative content of cellulose, high content of lignin, wider growth rings, higher contents of reaction wood, lower tangential volumetric shrinkage, higher longitudinal volumetric, lower percentage of autumnal wood, lower density, and lower mechanical strength (Haag et. al. 2019). However, these differences between juvenile and adult wood for certain species, the differences vary widely and must be evaluated individually, in addition to the general trends observed for all species, (but) these differences can be genetic, environmental or species-specific. (Haag et. al. 2019).

The differences that occur in the apparent density between juvenile and adult woods can be attributed to the genetic, age, physiology and growth rate of the tree. Some characteristics are undesirable for a certain purpose of wood using, therefore, the amount of juvenile wood must be carefully observed. Many factors, including silvicultural tracts, can positively or negatively affect the amount of juvenile wood (Cherelli, et. al. 2018).

Juvenile teak wood formed only by heartwood has $9.8 \%$ higher termite mortality than sapwood. However, it presents small loss of mass and wearing out, moderate mortality and the absence of perforations, which induces it to be classified as moderately resistant to dry wood termites, e.g., Cryptotermes brevis (Paes et al., 2015). The basic density, fiber length and lumen diameter of teak wood, aged 5 and 12 years, show increasing variations in the pith-bark direction, and these variations can be stabilized in wood from older trees that present a higher proportion of adult wood compared to juvenile wood (Gonçalves et al., 2007).

Teak logs aged between 4, 6 and 12 years, which have a higher proportion of juvenile wood than adult wood and have irregular partial type penetration and poor retention to CCA type $\mathrm{C}$ for use in the form of treated rounded posts. Thus, teak wood can be considered difficult to treat, not showing full CCA penetration throughout the permeable region (Chagas et al., 2014). Teak also has low permeability to preservative solutions when subjected to pressure impregnation. Due to physiological differences between juvenile and adult wood, there are differences in the impregnation and permeability by extractive materials along the heartwood regions, and this is most likely due to the presence of tyloses in different locations in the trunk and the disposition of vessels around the growth rings (Canal et al., 2020).

The speed of phase change from juvenile to adult wood is a trait under strong genetic control. This means that the amount of juvenile wood can be reduced through selection, which would influence the quality of juvenile wood, which also shows great variation between trees and can then be genetically improved (Zobel and Jett, 1995). Therefore, this is another aspect that must be considered when growing teak wood.

\subsection{Anatomical properties}

Studies of the types, dimensions and proportions of cells that constitute wood can determine the most suitable uses for each wood according to anatomical features (Burger and Richter, 1991). In Figure 3, we have an example of the anatomical 
structure of teak wood. In general, teak wood has distinct growth rings at the microscopic level (Figure 3a). Vessels arranged in semi-porous rings, without a defined arrangement, predominantly solitary and with the presence of multiple vessels of two and rare occurrence of multiple vessels of three or more (Figure 3a). Solitary vessels with a circular shape, with a tendency to oval, with or without tyloses presence of tyloses depends on location of trunk (Figure 3a and 4b). Sparse paratracheal axial parenchyma; multiseriate rays, five or more cells wide, homogeneous, formed exclusively by procumbent cells (Figure 3c). Libriform and short fibers; fiber wall is thin to thick, with predominant pits on the radial wall (Chagas et al., 2014).

Teak wood is semi-porous, where the growth rings are clearly differentiated, limited by dark bands of regular shape (Figure 3a), and the initial wood is composed of large diameter vessel elements with large void volume and the late wood is composed of a greater amount of woody material, that is, a greater amount of fibers with thicker walls and vessel elements of smaller diameter (Garcia and Marinonio, 2016; Segura et al., 2020).

Figure 3. Anatomical structure of 32-year-old Tectona grandis wood: a) Cross section showing the porosity in semicircular ring, b) Length and diameter of vessel element, c) Radial section showing procumbent cells, d) tangential section showing ray characteristics.
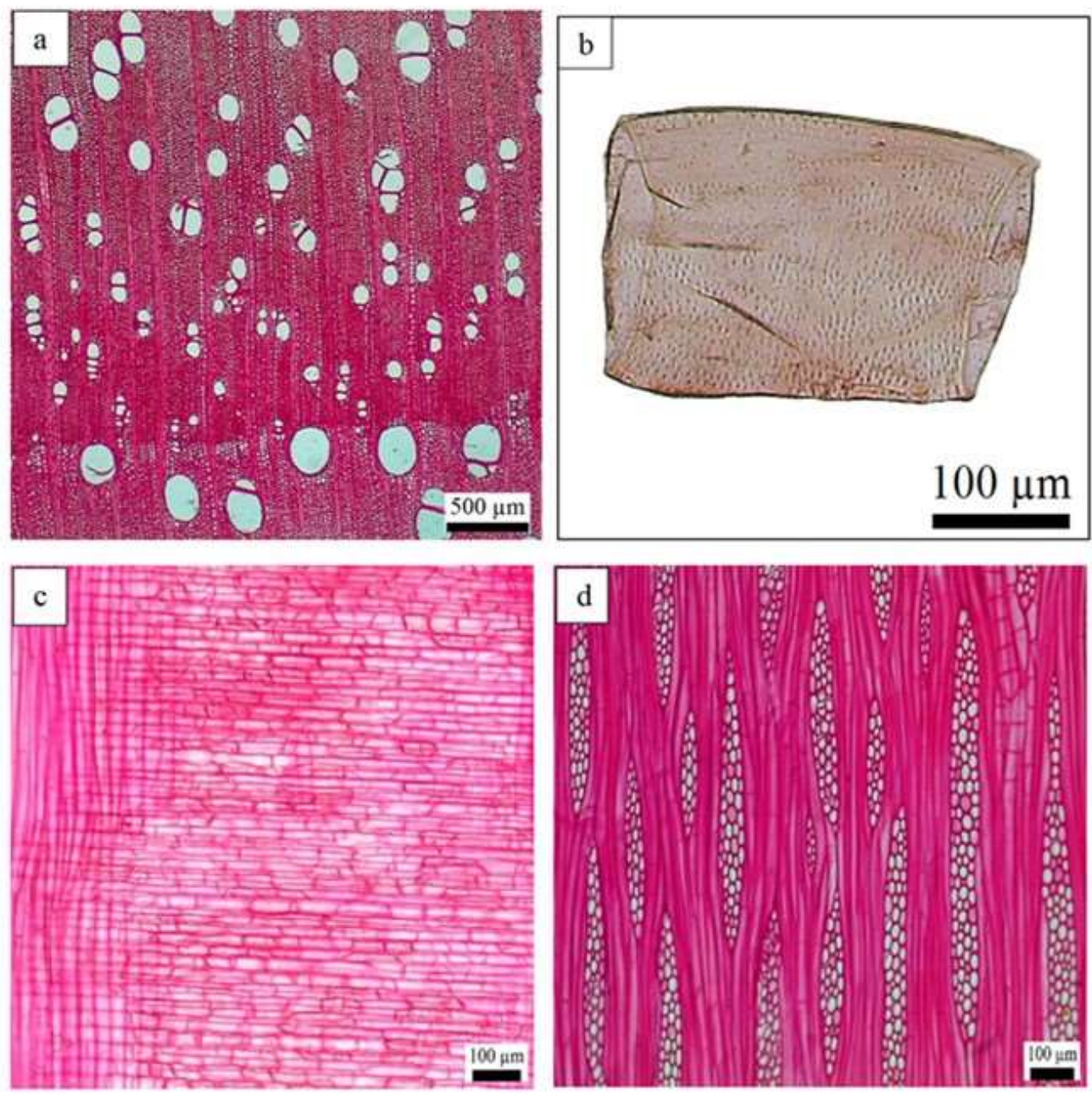

Source: Segura et al. (2020).

The cellular dimensions of wood can vary depending on several factors, and tree age is one of the most important to be analyzed. Thus, we have some mean values of teak cell dimensions obtained from research in Brazil (Table 1). It can be 
seen that fiber length, fiber wall thickness and vessel element diameter are the most evaluated anatomical elements by research already published in Brazil (Table 1).

Table 1. Wood features of Tectona grandis in Brazil as a function of age.

\begin{tabular}{|c|c|c|c|c|c|c|c|c|c|}
\hline $\begin{array}{c}\text { Age } \\
\text { (years) }\end{array}$ & $\begin{array}{c}\text { FL } \\
(\mu \mathrm{m})\end{array}$ & $\begin{array}{l}\text { FWT } \\
(\mu \mathrm{m})\end{array}$ & $\begin{array}{l}\text { VEL } \\
(\mu \mathrm{m})\end{array}$ & $\begin{array}{l}\text { VD } \\
(\mu \mathrm{m})\end{array}$ & $\begin{array}{c}\mathrm{VF} \\
\left(\mathrm{n}^{\mathrm{o}} \mathrm{mm}^{-2}\right)\end{array}$ & $\begin{array}{c}\mathrm{RH} \\
(\mu \mathrm{m})\end{array}$ & $\begin{array}{l}\text { RW } \\
(\mu \mathrm{m})\end{array}$ & $\begin{array}{c}\mathrm{RF} \\
\left(\mathrm{n}^{\mathrm{o}} \mathrm{m}^{-1}\right)\end{array}$ & $\begin{array}{c}\text { Source: } \\
\text { adapted from }\end{array}$ \\
\hline 4 & 940 & 4.32 & - & 105 & 5.00 & 510 & - & - & Chagas et al. (2014) \\
\hline 5 & 1158 & - & - & - & - & - & - & - & Gonçalves et al. (2007) \\
\hline 6 & 1120 & 4.79 & - & 121 & 7.00 & 590 & - & - & Chagas et al. (2014) \\
\hline 7 & 893 & 4.30 & - & 109 & 6.50 & - & - & - & Gil et al. (2018) \\
\hline 9 & 1037 & 4.24 & 303 & 170 & 10.95 & & & & $\begin{array}{l}\text { Benedetti (2018) } \\
\text { Queiroz (2018) }\end{array}$ \\
\hline 10 & 1173 & 4.46 & 274 & 165 & 4.07 & - & - & - & Benedetti (2018) \\
\hline 12 & 1067 & 4.50 & - & 168 & 5.00 & 510 & - & - & $\begin{array}{l}\text { Chagas et al. (2014) } \\
\text { Gonçalves et al. (2007) }\end{array}$ \\
\hline 13 & 1090 & 4.76 & 287 & - & - & - & - & - & Flórez (2012) \\
\hline 14 & 1118 & 6.13 & 295 & 172 & 5.87 & 790 & 69 & 5.48 & $\begin{array}{c}\text { Benedetti (2018) } \\
\text { Souza (2019) }\end{array}$ \\
\hline 16 & 1090 & 5.01 & 280 & 180 & - & 620 & 66 & 4.88 & Souza (2019) \\
\hline 17 & 1035 & - & - & - & - & - & - & - & Coneglian et al. (2016) \\
\hline 19 & 1360 & 4.41 & 296 & 183 & 4.90 & - & - & - & Benedetti (2018) \\
\hline 31 & 1109 & 6.54 & 317 & 153 & 8.28 & 500 & 52 & 7.16 & $\begin{array}{c}\text { Cardoso (1991) } \\
\text { Lima et al. (2011) }\end{array}$ \\
\hline
\end{tabular}

Fiber length (FL), fiber wall thickness (FWT), vessel element length (VEL), vessel diameter (VD), vessel frequency (VF), ray height (RH), ray width $(\mathrm{RW})$, and ray frequency $(\mathrm{RF})$. Source: Authors.

The fiber length of teak varies depending on tree age. However, it does not show a specific trend of increase or decrease (Table 1). Nonetheless, vessel element length behaves more stably (Table 1). For fiber wall thickness, there is also a variation very close to what occurred for fiber length, depending on tree age (Table 1). Teak wood presents variations in the pith-bark direction (Figure 4), for cell dimensions, with the length and thickness of the fiber wall significantly increasing in the pith-bark direction, i.e., close to the pith region we have the lowest values and close to the bark, the highest (Lima et al., 2011; Gil et al., 2018). In 17-year-old teak wood, it is possible to distinguish, in the pith-bark direction, from the radius of the log, two specific regions: one being a juvenile wood area, in the position between the pith up to $4 \mathrm{~cm}$, and the wood region mature, in the $6 \mathrm{~cm}$ position until the proximity of the bark (Coneglian et al., 2016). 
Figure 4. Pith-bark variation of fiber length (FL) and fiber wall thickness (FWT) in 31-year-old Tectona grandis wood

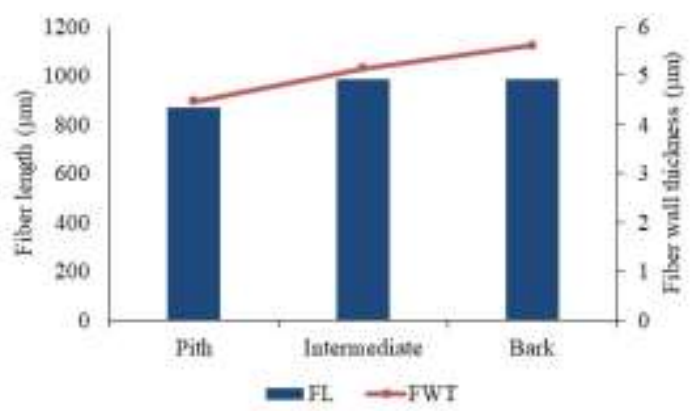

Source: adapted from Lima et al. (2011).

\section{4 chemical components}

Wood is basically made up of cellulose, hemicellulose, lignin and extractives. The combination of cellulose and hemicellulose is called holocellulose. These chemical components of wood are distributed in the cell walls of the anatomical elements that constitute the wood. These chemical components are responsible for physical and mechanical wood behavior, and are directly related to wood technological properties. Therefore, they are considered an important indicator of wood quality. In Figure 5, we have the chemical composition of teak wood as a function of age. For comparative purposes, the average values found in the literature were used as references. It can be seen that, increasing the age of the trees, there is an increase in the extractive content, and a decrease in the holocellulose content (Figure 5).

Figure 5. Chemical composition of Tectona grandis wood as a function of age.

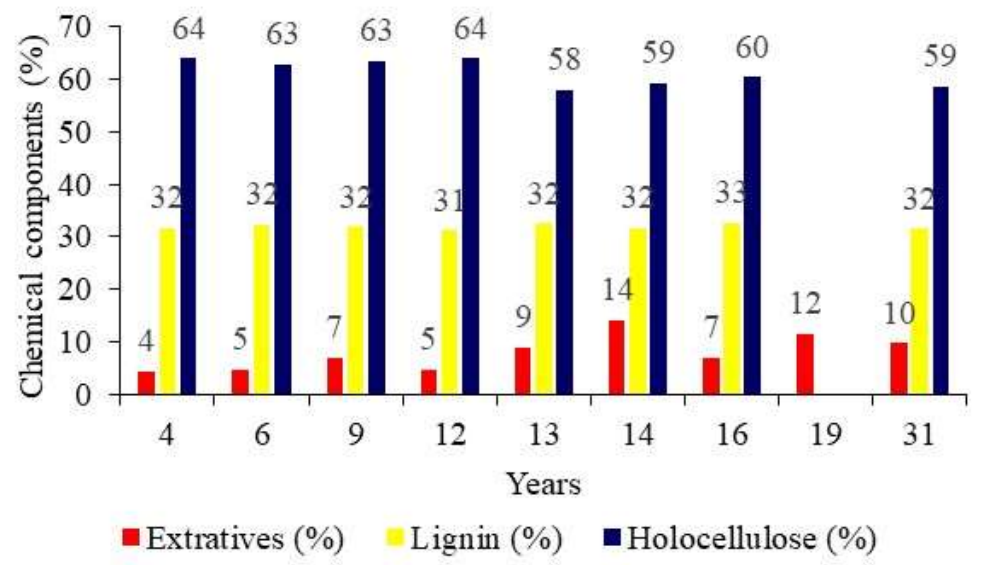

Source: adapted from Lobão et al. (2011); Flórez, (2012); Chagas et al. (2014); Oliveira et al. (2019); Queiroz, (2018); Benedetti, (2018); Souza, (2019).

Wood holocellulose content presents extreme commercial importance, as it constitutes a raw material for the manufacture of various products, such as cellulose, paper, ethanol, fabrics, in addition to countless other uses in the chemical and pharmaceutical industries (Chagas et al., 2014). The extractive content increases with the age of teak tree, up to the age of 14, and from this point onwards there is a trend towards stabilization (Canal et al., 2020). This increase in teak wood extractive content with tree age may be related to the wood natural durability, i.e, increasing the age, increases the proportion of heartwood, which contains more extractives. Therefore, the natural durability of teak wood is due to tectoquinone, which is an extract from the flavonoid class, which acts as a natural preservative. With this increase in the production of extractives as a function of tree age, there is an increase in the impregnation of tectoquinone in teak wood. However, teak wood with a high extractive content is not suitable for the bonding process. 
The lignin contents verified for teak wood in Figure 5 can be considered high, since values in the range of $20 \pm 4 \%$ are expected for hardwood (Klock et al., 2005). These high values of lignin contents can be undesirable in the pulp industry, however, it can be advantageous for energy purposes. In Table 2, we have the chemical composition of the teak wood, as a function of the sapwood and heartwood region. It can be seen that in the core region we have a higher content of extractives and a lower content of holocellulose. The sapwood has higher content of holocellulose because near to the bark, wood contains the most physiologically active cells, serving as an energy reserve, containing more starch and participating in the plant's conduction functions (Oliveira et al., 2019).

Table 2. Wood chemical composition of 6-year-old Tectona grandis sapwood and heartwood.

\begin{tabular}{cccc}
\hline & Extractives (\%) & Lignin $(\%)$ & Holocellulose $(\%)$ \\
\hline Sapwood & 4.89 & 32.42 & 62.69 \\
Heartwood & 7.18 & 32.87 & 59.95 \\
\hline
\end{tabular}

Source: Oliveira et al. (2019).

Teak wood has contents very close to lignin, both in the sapwood and in the heartwood region. One of the main factors affecting the natural resistance of wood is the difference in the extractives present, which are found in greater amounts in the core region of teak wood (Oliveira et al., 2019).

\subsection{Physical properties}

Among the physical properties of wood, we can highlight density, which is considered one of the main parameters of wood quality. The density value can be used to define the most suitable use of wood. Density is also related to other important quality parameters, such as anatomical, chemical and physical-mechanical. Among the wood densities, the basic density stands out, which is the ratio between the weight of the absolutely dry mass and the saturated volume. The basic density of wood can be altered depending on the characteristics of the species itself, external influences, environmental variations and silvicultural interventions. The causes of changes in wood density can be indirect, i.e., through the modification of other characteristics of the wood itself, to the detriment of inherent factors of the species or, therefore, of the influence that the environment in which it develops exerts (Latorraca, 2000).

In Figure 6 below, we have basic and apparent density values for teak wood planted in Brazil, as a function of tree age. It can be seen that there is a lot of variation between the materials analyzed, and there is no specific trend as a function of the age of the tree for this species. 
Figure 6. Density of Tectona grandis wood as a function of age.

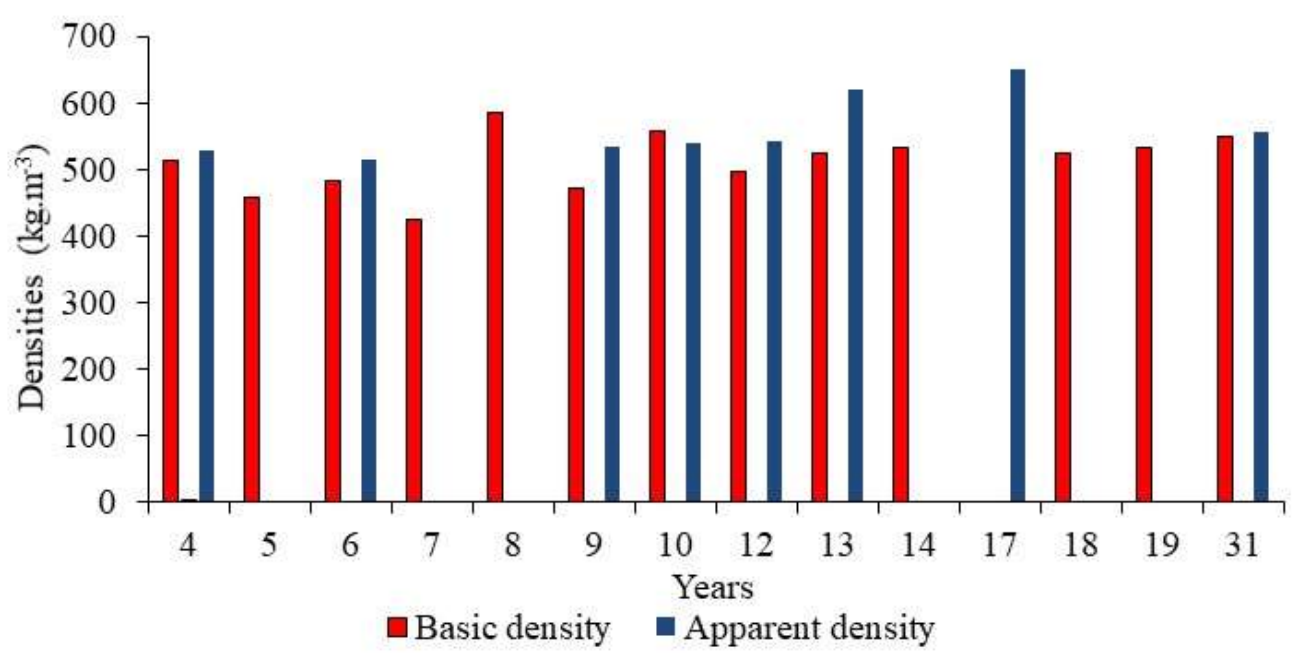

Source: adapted from Corrêa et al. (2019); Dias et al. (2018); Paes et al. (2015); Cremonez et al. (2015); Gil et al. (2018); Flórez, (2012); Queiroz, (2018); Oliveira et al., (2020); Benedetti, (2018); Souza, (2019); Silva, (2010); Bonduelle et al., (2015); Lima et. al., (2009).

This, however, can be beneficial for the use of forestry improvement when it is desired to select materials with more adequate density for certain purposes. Wood density tends to increase with age due to the increase in cell wall thickness and decrease in cell lumen, i.e., as the proportion of juvenile wood in the tree trunk decreases (Vital, 1984, Câmara et. al., 2020).

Another important physical property of wood is volumetric shrinkage, mainly for the use of wood for civil construction, furniture production and in the generation of other products with greater added value, such as doors, floors, frames, paneling, windows and others. In general, very strong variations in the dimensions and anisotropy of wood are undesirable characteristics. Because these variations can directly affect the dimensional stability and would make the use of wood for certain products unfeasible or would require more adequate wood processing and use techniques. In table 5 we have some results of volumetric shrinkage and anisotropy index of teak wood planted in Brazil.

The results demonstrate that teak wood in general has good dimensional stability, as the average volumetric shrinkage is below $10 \%$, thus resulting in medium quality wood compared to its use in solid products (Table 3). However, teak wood anisotropy index can be considered medium to high, as most values are above 1.5 and some are even above 2 (Table 3).

Table 3. Volumetric shrinkage $\left(\varepsilon_{\mathrm{v}}\right)$, and anisotropy index (T/R) of Tectonas grandis wood, as a function of tree age.

\begin{tabular}{cccc}
\hline Age (years) & $\varepsilon_{\mathrm{v}}(\%)$ & T/R & Source: \\
\hline 7 & 9.84 & 2.22 & Paes et al. (2015) \\
7 & 8.14 & 2.02 & Gil et al. (2018) \\
9 & 8.40 & 2.40 & Benedetti (2018) \\
9 & 8.89 & 1.34 & Queiroz (2018) \\
10 & 5.75 & 1.83 & Benedetti (2018) \\
12 & 8.53 & - & Silva (2010) \\
13 & 5.23 & 1.99 & Dias et al. (2018) \\
13 & 6.84 & 1.82 & Flórez (2012) \\
14 & 4.41 & 1.79 & Benedetti (2018) \\
14 & 6.80 & 1.76 & Souza (2019) \\
18 & 6.31 & 2.27 & Bonduelle et al. (2015) \\
19 & 5.22 & 1.82 & Benedetti (2018) \\
31 & 6.47 & - & Lima et al. (2009) \\
\hline
\end{tabular}

Source: Authors. 


\subsection{Mechanical properties}

Another parameter used to determine wood quality is the mechanical properties, which can be influenced by several factors, such as: species, age of the tree, position in the tree, moisture content, duration of load and structural constitution of the wood. For the use of teak wood as a building material, mainly in structural use, mechanical properties are basic requirements. According to their mechanical properties that teak wood presents, they are classified and grouped in the uses to which they are most suitable, being, therefore, very important with regard to the applications for which they will be destined. In table 6 below, we have some results of mechanical properties of teak planted in Brazil, depending on the age of the tree. It can be seen that, in general, the mechanical properties of planted teak in Brazil have relationship with the age of the trees. However, other factors may have contributed to this, such as: different origins, environmental factors and forest management.

Table 4. Strength in shear parallel to grain $\left(f_{v 0}\right)$, compression parallel to the grain $\left(f_{c 0}\right)$, Janka hardness $\left(f_{H}\right)$, modulus of rupture (MOR) and modulus of elasticity (MOE) in static bending from Tectonas grandis wood planted in Brazil.

\begin{tabular}{|c|c|c|c|c|c|c|}
\hline $\begin{array}{c}\text { Age } \\
\text { (years) }\end{array}$ & $\begin{array}{c}\mathrm{f}_{\mathrm{v} 0} \\
(\mathrm{MPa})\end{array}$ & $\begin{array}{c}\mathrm{f}_{\mathrm{c} 0} \\
(\mathrm{MPa})\end{array}$ & $\begin{array}{c}\mathrm{fH}_{\mathrm{H}} \\
\text { (kgf) }\end{array}$ & $\begin{array}{l}\text { MOR } \\
(\mathrm{MPa})\end{array}$ & $\begin{array}{l}\mathrm{MOE} \\
(\mathrm{MPa})\end{array}$ & Source: \\
\hline 7 & & & & 86.16 & 9055 & Paes et al. (2015) \\
\hline 9 & 12.77 & 34.04 & 324 & 83.38 & 10203 & Benedetti (2018) \\
\hline 9 & & 39.41 & 349 & 91.86 & 9241 & Queiroz (2018) \\
\hline 10 & 16.40 & 41.71 & 411 & 98.52 & 11182 & Benedetti (2018) \\
\hline 10 & & & 470 & & & Cremonez, et. al. (2015) \\
\hline 13 & & 48.00 & 451 & 94.00 & 13304 & Flórez (2012) \\
\hline 13 & & & 595 & & & Cremonez, et. al. (2015) \\
\hline 14 & 14.33 & 38.54 & 355 & 91.63 & 10233 & Benedetti (2018) \\
\hline 14 & & & & 103.00 & 11207 & Souza (2019) \\
\hline 17 & & & 683 & & & Cremonez, et. al. (2015) \\
\hline 19 & 16.41 & 41.98 & 354 & 98.74 & 12172 & Benedetti (2018) \\
\hline 32 & 11.43 & 46.93 & & 102.20 & 11775 & Lima et. al. (2011) \\
\hline
\end{tabular}

Source: Authors.

\subsection{Energy wood properties}

In general, teak wood has good quality, but when it comes from the first thinning at young ages, it is most often used as firewood for energy, as the quality of wood at these younger ages is still doubtful, being an obstacle for the indication of a use with greater added value.

The high heating value of teak of the first thinning carried out at 5 years is $4.557 \mathrm{Kcal}_{\mathrm{kg}}{ }^{-1}$, and of the second thinning

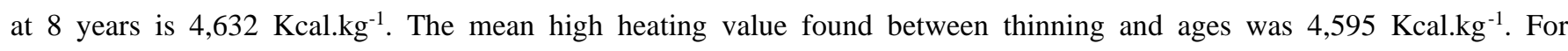
immediate chemical analysis of thinning wood, we have values of $80.37 \%$ of volatile materials; $18.39 \%$ for fixed carbon; $0.59 \%$ for ash content. The fixed carbon content in teak wood presents higher values when compared to Eucalyptus spp., which characterizes a better wood for burning. However, the ash content was higher than that found in the literature, which does not disqualify it for use as an energy source, since being below $1 \%$, it is within acceptable standards for wood-type biomass (Silva et al., 2015). 


\section{Effect of Forest Management on the Tectona grandis Wood Quality}

The main objective to be achieved in the forest management of teak would be to reconcile the highest productivity with the best quality of wood for a specific use. The worldwide demand for teak wood revolves around the trade in exceptional quality wood and logs. However, inferior quality wood presents clear commercialization difficulties, as most importers require wood without any sapwood. This is only possible in more mature stands, therefore, with ages from 20 years onwards, it is not only linked to the diameter of the logs sold, but also to the lower percentage of juvenile wood and knot-free pieces. The quality of wood from young teak plantations needs comparison with traditional long rotation plantations. However, we must highlight that teak produced in Brazil is normally from plantations that were not managed with thinning and pruning techniques, which can make it difficult to assess the quality of the wood more carefully.

The rapid initial growth of trees of many species may be directly related to the formation of juvenile wood. However, the period of changes in wood properties may be independent of the speed of growth, i.e., both in fast and slow growth, the dimensions and morphology of wood cells change when related to other wood properties (Silva et al., 2020).

The planting spacing of $3 \mathrm{~m} \times 2 \mathrm{~m}$ (1,667 tree/ha) is indicated in teak planting, when it is desired to obtain greater growth without perception of competitive effects, aiming at the production of wood for sawmills (Macedo et al., 2005). However, in order to obtain larger trees, at the end of the cycle, a thinning operation is recommended, from the age of 5 years old onwards, however, always with the support of the forest inventory, which allows a more judicious intervention. The teak forestry management aimed at producing larger wood must also include the pruning operation, which consists of removing the side branches up to $50 \%$ of the tree or commercial bole, this operation aims at the formation of boles clean without knot.

Considering that larger spacing can produce a greater volume of wood per unit area, it can, which can cause a gain in wood density when this is proportional, to the increase in spacing. However, this is only true if the increase in volume is more than proportional to the increase in density, which would enable an increase in dry mass produced per unit of area (Lima et al., 2009).

The evaluations of the physical and anatomical characteristics of teak thinning wood, at age seven, indicated that the structures formed by the cambium have not yet reached the stabilization of their dimensions, not being suitable for the applications of adult teak wood as in shipbuilding and furniture (Gil et al., 2018).

The cultivation of intercropped teak in agroforestry systems maintained its technological qualities in terms of basic density, which would be an advantage for managing the forest for multiple uses (Oliveira et al., 2020). The 19-year-old teak wood cultivated in an agroforestry system, in general, has an average basic density around $480 \mathrm{~kg} . \mathrm{m}^{-3}$, and this result was similar to the values obtained in monoculture conditions, and presented values with low amplitude in the base-top direction, which can maximize the use of wood for the most diverse applications (Corrêa et al., 2019). The climate, rainfall and site quality influence the locations of $T$. grandis plantations and produce substantial variation in the dimensions of wood fibers and radii (Souza, 2019).

Growing T. grandis plantations on sloping terrain can stress the wood. The deviation of the pith in relation to the geometric axis of the $\log$ is generally an indication that the trees grew in conditions of inclination, whether due to the slope of the terrain, wind action, architecture or movement of the crown and that, consequently, caused the formation of wood reaction (Boschett et.al. 2015). Among different genetic materials of $T$. grandis there are no marked differences related to carbon content. However, the differences are more pronounced between wood and bark than heartwood and sapwood (Sanquetta et al., 2016). 


\section{Genetic Improvement of Tectona grandis Wood}

The genetic improvement programs for Tectona grandis are recent in Brazil, basically focusing on the development of clones. Initially, the main focus is the growth characters and some wood properties, mainly the basic density. For the application and choice of selection methods in teak, genetic variations and additives and non-additives, heritability in the narrow and broad sense, and genetic correlations between characters are important. As in other forestry improvement programs, it is common to convert progeny tests and seed orchards to faster production of commercial clones or seed orchards. Therefore, new geographical origins must be tested in relation to the national territory (Schuhli \& Paludzyszyn, 2010).

The heartwood and sapwood relationship of teak wood is also an important factor in the selection of genetic material, which is already starting to be used in forestry improvement in Brazil. In the comparison of clonal and seminal teak material, it was found that the percentage of heartwood and sapwood of teak wood or clonal material presents a higher proportion of heartwood compared to the seminal material, with a gain of $66 \%$ in heartwood production. It can also be highlighted that the irregularity in the production of the core of the seminal material is remarkable, demonstrated by the high coefficient of variation, $48.04 \%$. The clonal material presented a coefficient of variation of $14.57 \%$. Cloning enables the production of more uniform raw material, which, from an industrial point of view, has benefits, both in the minimization of costs in the industrial process and in the quality of the products, so with teak cloning it is possible to associate greater volumetric productivity with higher percentages of heartwood (Oliveira et al., 2019).

\section{Mechanical Processing of Tectona grandis Wood}

Teak tree plantations, when properly managed, can provide wood considered noble, of excellent quality. However, the processing of teak logs must be done as soon as possible, within a maximum period of one week, after the trees are felled. Therefore, delay in unfolding should be avoided, as this could lead to the development of more intense cracks in the boards during unfolding, which would accumulate after the drying period (Paes et al., 2015).

In the mechanical processing of $\operatorname{logs}$, the sawn wood yield is the main factor to be analyzed in the performance of a sawmill. Teak wood presents an average commercial yield of the barkless tree around 37.43\%. However, there is a lot of variation between the analyzed materials from different provenance and origins (Queiroz, 2018).

In a study on teak log splitting yield where two types of cuts were analyzed, the average gross yield for the shaftparallel (SP) cutting method was $48.02 \%$ and for the bark-parallel cutting method (BP) was $51.55 \%$ (Figures 7A and 7B). However, there was no significant difference for yield between the two types of cut analyzed. The only defect found during break-down and drying of teak wood was the presence of cracks in the wood, but they did not differ according to the types of cut evaluated (Carmo et al., 2020). 
Figure 7. shaft-parallel cut (A) and bark-parallel (B).
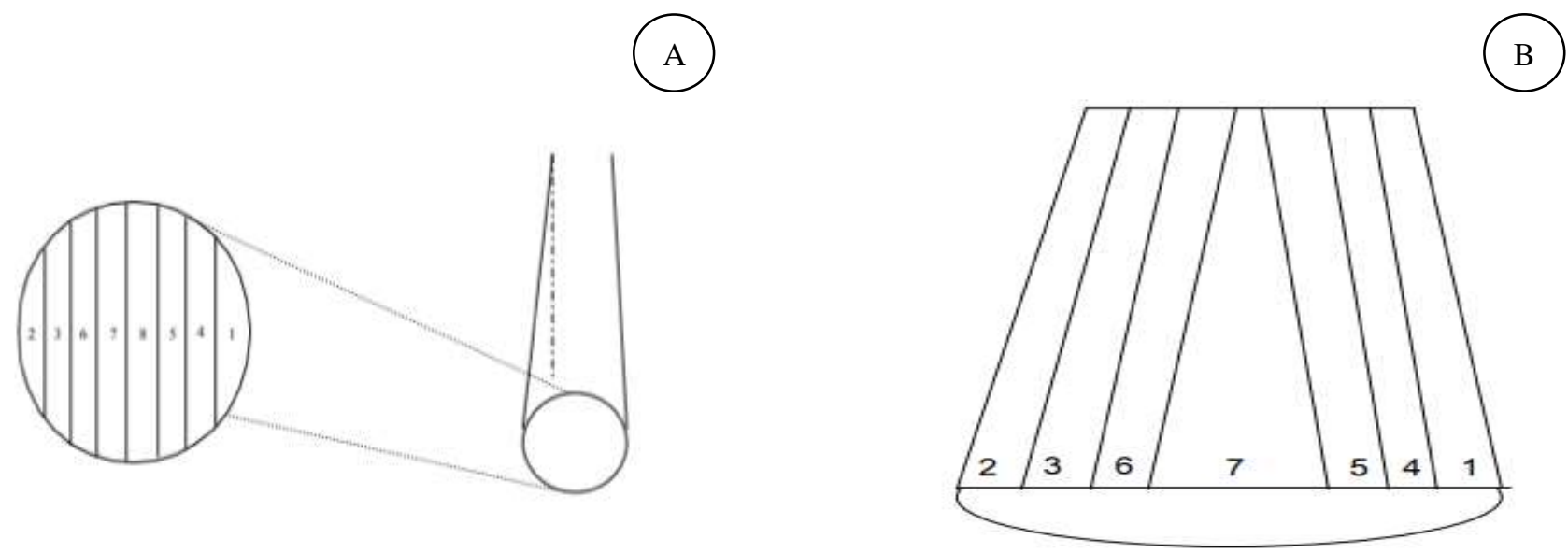

Source: Carmo et al. (2020).

Juvenile teak wood presents easy machining, workability, gluing and finishing, having the potential to be used in the furniture industry. In the manufacture of furniture, this wood meets the desired aesthetic and finishing characteristics, adding value to the product from the first thinning, currently considered a waste and used for purposes with lower added value (Paes et al., 2015).

The wood processing activities in furniture factories are characterized by different types of machining processes, differing according to the function of the piece. Teak has good workability in sawing, planning, turning, drilling, sanding, milling and gluing operations. The presence of silica in teak wood can cause tools to wear out. Both sapwood and heartwood contain a latex-like substance called rubber, which reduces water absorption and lubricates wood surfaces. This substance also provides acid resistance and protects nails and screws from corrosion, that is why teak wood is so used to build boats, pool decks and outdoor furniture.

\section{Drying Tectona grandis Wood}

The wood drying process consists of reducing the moisture content in order to bring it to a defined value, with a minimum of defects, in the shortest possible time, and in an economically viable way for the intended use. The reasons it is important to dry the wood are as follows: reduction of dimensional movement to acceptable limits, improvement in the performance of varnishes and paints applied on the wood, reduction of the richness of the attack of wood xylophages agents, improvement in the quality of joints, gluing, greater impregnation of wood with preservative and fire-retardant liquids, increases mechanical resistance, reduces transport weight, improves workability characteristics (planning, sanding and drilling), improves the fixation of nails and screws and improves electrical and acoustic insulation properties (Benedetti, 2018; Bonduelle et al., 2015).

Teak wood does not present much difficulty in drying, as this process is considered slow, with very few defects occurring. The air drying quality of $40 \mathrm{~mm}$ teak wood planks can be considered good for a shelter condition, mainly for two reasons: i) the average moisture content thickness gradients were comparable to those reported in the literature for drying in greenhouse with thinner boards; ii) the range of moisture content between the boards was satisfactory for a drying process in an uncontrolled environment (Batista et. al. 2017). In Figure 8, we have a drying curve for teak wood, where it can be noted that stabilization occurs at close to $12 \%$ moisture (Braz et al., 2015). 
Figure 8. Outdoor drying curves of 15-year-old Tectona grandis wood.

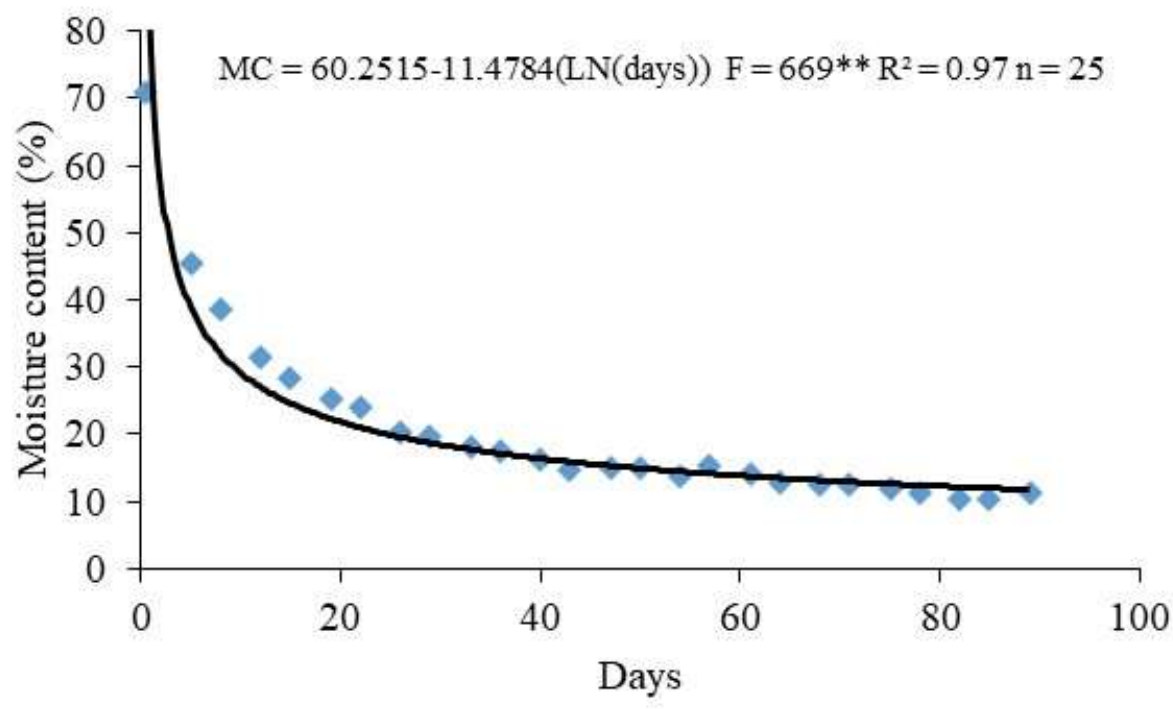

Note: $* *$ Significant differences at $\mathrm{p}<0.01$;

Source: adapted from Braz et al. (2015).

To be properly handled by the furniture industry, teak wood needs to go through a drying process, which is why this activity is one of the most important in the industrialization of wood.

\section{Other Uses of Tectona grandis Wood}

Wood-based panels represent an excellent option for the industrial use of wood, having the following advantages: material reliability, piece stability, possibility of making pieces whose dimensions are not found in solid wood and use in modern and complex applications with low cost-efficiency. Teak wood has the potential to be used for the manufacture of particle boards with the addition of waste generated by agribusiness, these panels have applicability in the furniture industry and civil construction (Nasser, 2019). Another option for the use of teak wood panels would be the production of homogeneous particle boards using teak wood and another species (Gilio, 2020). Young teak wood can be used in the manufacture of lath panels glued sideways as EGP (Edge Glued Panel) to be used in the furniture industry and civil construction, and also in the production of handicrafts and small objects (Paes et al., 2015).

The production of teak wood floors can be one of the best ways to use this wood. For, floors made from this material are of the highest standard, mainly due to their aesthetic beauty, due to the contrast between sapwood and heartwood, as they are of different shades (Flórez et al., 2015). In general, teak wood presents result of Janka hardness resistance and apparent density close to species traditionally used for the production of floors and these values improve with increasing age, so to be used the floor production must be older. However, the management of younger teak forest, with a cycle of around 10 years, but well managed, may allow the use of wood from thinning for this purpose (Benedetti, 2018; Cremonez et al., 2015).

\section{General Considerations of Tectona grandis Wood}

Teak wood planted in Brazil, in general, has a certain variability in its technological properties, and these variations are due to origin, genetic material, age, planting location and cycle used in forest management. Teak planted in Brazil has shown values that match its properties with wood planted in the countries of origin. Teak has shown potential to be used as 
lumber, lamination, panel manufacturing, flooring and furniture manufacturing in general. Many of the results of surveys on the evaluation of the properties of teak wood produced in Brazil are normally from plantations that were not managed with thinning and pruning techniques, which can make it more difficult to carry out a more careful evaluation of the wood.

In general, we still do not have much research on the quality of teak wood, and it is important to implement research and experiment programs that consider the different genetic materials, growing environments, planting spacing, silvicultural treatments and cutting ages, to allow for greater knowledge about the growth and factors that can influence the quality of the wood produced and the adjustments that can help in the management of the forest, in the processing and in the use of wood, in order to consider the best cost-benefit ratio. Despite this promising condition, there are still many doubts about the management of teak for the production of wood with a quality compatible with that of the countries of origin of this species. Existing studies can also direct further research on teak production and quality.

\section{References}

Batista, D. C., Oliveira, J. T. S., Pizetta, R. P., \& Lube, V. M. (2017). Quality Assessment of Air-dried Teakwood Boards Using Moisture Content Gradients. Floresta e Ambiente, 24, 1-7.

Benedetti, V. (2018). Caracterização da madeira de teca plantada em diferentes idades e regiões para produção de piso. (Tese de Doutorado), Universidade de São Paulo, Piracicaba.

Bonduelle, G. M., Iwakiri, S., Trianoski, R., Prata, J. G., \& Rocha, V. Y. (2015). Análise da densidade e da retratibilidade da madeira de Tectona grandis nos sentidos axial e radial do tronco. Floresta, 45, 671-680.

Boschetti, W. T. N., Paes, J. B., Oliveira, J. T. D. S., \& Dudecki, L. (2015). Anatomical characteristics for cellulose production of reaction wood of inclined eucalypt trees. Pesquisa Agropecuária Brasileira, 50, 459-467.

Burger, L. M., \& Richter, H. G. (1991). Anatomia da madeira. Nobel.

Braz, A. L., Duarte, A. P. C., Oliveira, J. T. S., Motta, J. P., \& Rosado, A. M. (2015). Curva característica de secagem da madeira de Tectona grandis e Acacia mangium ao ar livre. Revista Florestal e Ambiente, 22, p. 117-123.

Canal, W. D., Carvalho, A. M. M. L., Carneiro, A. C. O., Vidaurre, G. B., Freitas, F. P., \& Magalhes, M. A. (2020). Effect of age on heartwood/sapwood relationship, extractive content, and permeability of teak wood. Floresta, 50, 1698-1706.

Cardoso, N. S. (1991). Caracterização da estrutura anatômica da madeira, fenologia e relações com a atividade cambial de árvores de teca (Tectona grandis) Verbanaceae. (Dissertação de Mestrado), Universidade de São Paulo, Piracicaba.

Câmara, A. P., Vidaurre, G. B., Moulin, J. C., \& Bobadilha, G. S. (2020). A relação cerne e alburno na madeira de eucalipto. In: Graziela Baptista Vidaurre; João Gabriel Missia da Silva; Jordão Cabral Moulin; Angélica de Cássia Oliveira Carneiro. (Org.). Qualidade da madeira de eucalipto proveniente de plantações no Brasil. EDUFES: Vitória.

Carmo, J. F., Carmo, F. H. D. J., Miranda, D. L. C., Volpato, M., \& Teixeira, K. T. (2020). Influência do desdobro tangencial no rendimento e na qualidade da madeira de Tectona grandis L. f. Brazilian Journal of Animal and Environmental Research, 3, 808-814.

Chagas, S. F., Evangelista, W. V., Silva, J. C., \& Carvalho, A. M. M. L. (2014). Propriedades da madeira de teca de diferentes idades e oriundas de desbaste. Brazilian Journal of Wood Science, 5, 138-150.

Cherelli, S. G., Sartori, M. M. P., Próspero, A. G., \& Ballarin, A. W. (2018). Heartwood and sapwood in eucalyptus trees: non-conventional approach to wood quality. Anais da Academia Brasileira de Ciencias, 90, 425-438.

Coneglian, A., Campos, N. P., Sette Júnior, C. R., Silva, A. D., Sousa Júnior, A. D., Pereira, I. M. (2016). Using segmented linear regression to identify juvenile and mature wood of Tectona grandis. International Journal of Current Research, 8, 42021-42024.

Corassa, J. N. Castelo, P. A. R., Stangerlin, D. M., \& Iris Cristina Magistrali, I. C. (2013). Durabilidade natural da madeira de quatro espécies florestais em ensaios de deterioração em campo. Brazilian Journal of Wood Science, 4, 108-117.

Corrêa, F. L. O., Santos, C. M. M., Moretti, S. D. A., Mascarenhas, A. R. P., Melo, R. R., \& Vitória, M. H. (2019). Massa específica e teor de umidade da madeira de teca (Tectona Grandis LF) cultivada em sistema agroflorestal multiestratificado em Rondônia. In XI Congresso Brasileiro de Sistemas Agroflorestais: Diversidade e Oportunidade.

Cremonez, V. G., Zen, L. R., Klitzke, R. J., Rocha, M. P., \& França, M. C. (2015). Infuence of the age on specific gravity and Janka hardness in the wood of teak (Tectona grandis L.f.) for floor. Australian Journal of Basic and Applied Sciences, 35, 300-305.

Dias, A. C. C., Marchesan, R., Almeida, V. C., Monteiro, T. C., \& Moraes, C. B. (2018). Relação entre a densidade básica e as retrações em madeira de teca. Ciência da Madeira, 9, 37-44.

Figueiredo, E. O., \& De Sa, C. P. (2015). Silvicultura e manejo de povoamentos de Teca (Tectona grandis Lf). Embrapa Acre-Documentos (INFOTECA-E). 
Figueiredo, E. O., Oliveira, L. C., \& Barbosa, L. K. F. (2019). Teca (Tectona grandis L.F.): principais plantas do futuro empreendedor florestal. Rio Branco: https://www.infoteca.cnptia.embrapa.br/infoteca/handle/doc/504317.

Finger, F. A., Finger, Z., \& Barros, N. (2003). Qualificação da madeira de teca, Tectona grandis 1. f., oriunda do primeiro desbaste comercial, com vistas a seu aproveitamento. Madeira: Arquitetura e Engenharia, 4, 1-30.

Flórez, J. B. (2012). Caracterização tecnológica da madeira jovem de teca (Tectona grandis Lf). (Dissertação de Mestrado), Universidade Federal de Lavras, Lavras.

Flórez, J. B., Silva, J. R M., Braga, P. P. C., Lima, J. T., \& Trugilho, P. F. (2015). Simulação em serviço de pisos de madeira jovem de Tectona grandis. Revista Matéria, 20, 1048-1060.

Garcia, R. A., \& Marinonio, G. B. (2016). Variação da cor da madeira de teca em função da densidade e do teor de extrativos. Floresta e Ambiente, 23, 124134.

Gil, J. L. R. A., Barboza, F. S., Coneglian, A., Silva, M. F., Moraes, M. D. A., \& Sette Jr., C. R. (2018). Características físicas e anatômicas da madeira de Tectona grandis Lf aos 7 anos de idade. Revista de Ciências Agrárias, 41, 261-270.

Gilio, C. G. (2020). Avaliação de painéis de partículas homogêneas empregando-se madeira de Hevea brasiliensis e Tectona grandis, aglutinadas com adesivo poliuretano derivado de óleo de mamona. (Dissertação de Mestrado), Universidade Estadual Paulista, Ilha Solteira.

Gonçalves, M.P.M. Coffler, R., Carvalho, A. M., \& Garcia, R. A. (2007). Variação radial da densidade básica e do comprimento das fibras da madeira de Tectona grandis L. Floresta e Ambiente, 14, 70-75.

Haag, V., Koch, G., Richter, H. G., Evans, R., Guzmán, J. A. S., \& Schmitt, U. (2019). Wood anatomical and topochemical analyses to characterize juvenile and adult wood of lesser-known species from Central America (Mexico). IAWA Journal, 40, 785-803.

IBÁ. Indústria Brasileira de Árvores (2019). Relatório Ibá 2019. https://iba.org/datafiles/publicacoes/relatorios/iba-relatorioanual2019.pdf.

Jankowsky, I. P. (1979). Madeira juvenil, formação e aproveitamento industrial. IPEF. Circular técnica, n. 81, p. 18.

Kokutse, A. D. Bailleres, H.; Stokes, A.; \& Kokou, K. (2004). Proportion and quality of heartwood in Togolese teak (Tectona grandis Lf). Forest Ecology and Management, 189, 37-48.

Klock, U., Muniz, G. I. B., Andrade, A. S., \& Anzaldo, J. H. (2005). Química da Madeira. Fundação de Pesquisas Florestais do Paraná - Fupef: Curitiba.

Lamprecht, H. (1990). Silvicultura nos trópicos. GTZ: Eschborn.

Latorraca, J. V. F, \& Albuquerque, C. E. C. (2000). Efeito do rápido crescimento sobre as propriedades da madeira. Floresta e Ambiente, 7, $279-291$.

Lima, I. L., Garcia, R., Longui, E. L., \& Florsheim, S. M. B. (2011). Dimensões celulares da madeira de Tectona grandis Linn. em função do espaçamento e posição radial. Scientia Forestalis, 39, 61-68.

Lima, I. L., Florsheim, S. M. B., \& Longui, E. L. (2009). Influência do espaçamento em algumas propriedades físicas da madeira de Tectona grandis Linn. Cerne, 15, 244-250.

Lima, I. L., Pimentel, M. M., \& Garcia, J. N. (2011). Propriedades mecânicas e densidade aparente da madeira de Tectona grandis Linn. F. (teca) em função do espaçamento e da posição radial na tora. Silva Lusitana, 19, 221-232.

Lobão, M. S., Castro, V. R., Rangel, A., Sarto, C., Tomazello Filho, M., Silva Júnior, F. G., Lauro de Camargo Neto, L. C., \& Bermudez, M. A. R. C. (2011). Agrupamento de espécies florestais por análises univariadas e multivariadas das características anatômica, física e química das suas madeiras. Scientia Forestalis, 39, 469-477.

Lorenzi, H., Hermes, H. M., \& Torres, M. A. V. (2003). Árvores exóticas no Brasil: madeireiras, ornamentais e aromáticas. Instituto Plantarum: Nova Odessa.

Macedo, R. L. G., Gomes, J. E., Venturin, N., \& Salgado, B. G. (2005). Desenvolvimento inicial de Tectona grandis L.f. (TECA) em diferentes espaçamentos no município de Paracatu, MG. Cerne, 11, 61-69.

Malan, F. S. (1995). Eucalypts improvement for lumber production. In Seminário internacional e utilização da madeira de eucalipto para serraria, São Paulo, 1995. Anais. Piracicaba: IPEF; IPT; IUFRO; ESALQ.

Motta, J. P., Oliveira, J. T. S., Paes, J. B., Alves, R. C., \& Dambroz, G. B. V. (2013). Resistência natural da madeira de Tectona grandis em ensaio de laboratório. Ciência Rural, 43, 1393-1398.

Nasser, S. M. (2019). Painéis de partículas de madeira da espécie Teca e casca de amendoim com adesivo à base e mamona. (Tese de Doutorado), Universidade Estadual Paulista, Bauru.

Oliveira, A. C., Pereira, B. L. C., Silva Mendes, M. C., Santos Lemos, J. A., \& Madi, J. P. S. (2019). Influência do método de propagação na produção e qualidade da madeira de Tectona grandis. Advances in Forestry Science, 6, 761-765.

Oliveira, J. K. Mendoza, Z. M. S. H., Borges, P. H. M., Elias, M. P. S., Barros, J. M. R., \& Morais, P. H. M. (2020). Massa específica básica da madeira de Tectona grandis proveniente de sistema agrossilvipastoril. Brazilian Journal of Development, 6, 1-10.

Oliveira, W. C. D., Pereira, B. L. C., Goes, L. S. A., Quintilhan, M. T., Oliveira, A. C., \& Môra, R. (2019). Deterioration of teak wood in accelerated decay test. Floresta e Ambiente, 26, 1-9. 
Research, Society and Development, v. 10, n. 14, e162101421549, 2021

(CC BY 4.0) | ISSN 2525-3409 | DOI: http://dx.doi.org/10.33448/rsd-v10i14.21549

Paes, J. B., Santos, L. L., Silva, L. F., Motta, J. P., Braz, R. L., \& Lombardi, L. R. (2015). Caracterização tecnológica da madeira juvenil de teca (Tectona grandis) visando à produção de móveis. Revista Brasileira de Ciências Agrárias, 10, 437-442.

Paes, J.B., Guerra, S. C. S., Silva, L.F., Oliveira, J. G. L., \& Teago, G. B. S. (2016). Efeito do teor de extrativos na resistência natural de cinco madeiras ao ataque de cupins xilófagos. Ciência Florestal. 26, 1259-1269.

Pimentel, M. M., Selegato, P. A. M., Garcia, J. N., \& Lima, I. L. (2008). Variação de propriedades da madeira de Tectona grandis Linn. F. (teca) em função do espaçamento e da posição radial na tora. IF Série Registros, 36, 19-24.

Pires, W. K., Mariano, G. V. P., Furtado, J. S., Araújo, M. S., \& Silva, A. C. (2020). Estudo econômico da implantação de Tectona grandis L.f. Revista do Instituto Florestal, 32, 7-16.

Queiroz, F. L. C. (2018). Qualidade da madeira de Tectona grandis L. f. de diferentes procedências para utilização na indústria de produtos florestais. (Tese de Doutorado), Universidade de Brasília, Brasília.

Sanquetta, M. N. I., Sanquetta, C. R., Mognon, F., Corte, A. P. D., \& Maas, G. C. B. (2016). Wood density and carbon content in young teak individuals from Pará, Brazil. Científica, 44, 608-614.

Segura, C. E. C., Rocha, M. P., Klitzke, R. J., \& Héctor, E. G. M. (2020). Caracterización anatómica radial y axial de la madera de teca (Tectona grandis L. f.) plantada en Chanchamayo-Perú. Brazilian Journal of Wood Science, 11, 1-14.

Schuhli, G.S., \& Paludzyszyn Filho, E. (2010). O cenário nacional da silvicultura de teca e perspectivas para o melhoramento genético. Pesquisa Florestal Brasileira, 30, 217-230.

Silva, D. M. R. (2010). Avaliação das propriedades físicas e da elasticidade da madeira de Tectona grandis 1.f. proveniente de povoamento com três densidades de plantio em Cáceres-MT. (Trabalho de conclusão de curso), Rio de Janeiro, Seropédica.

Silva, D. A., Christo, E. R., Belhing, A., Mayer, S. L. S., Pelanda, K. A., \& Simetti, R. (2015). Potencial e qualidade da madeira de desbaste de teca para produção de biocombustível. Pesquisa Florestal Brasileira, 35, 299-305.

Souza, R. S. (2019). Propriedades tecnológicas de Tectona grandis proveniente de sítios distintos. (Tese de Doutorado), Universidade de Brasília, Brasília.

Vital, B.R. Métodos de determinação da densidade da madeira. Boletim Técnico SIF, 1, 1-21, 1984.

Zobel, B. (1981). Wood quality from fast-grown plantations. Tappi, 64, 17-74.

Zobel, B. J., \& Jett, J. B. (1995). Genetics of wood production. Springer-Verlag. 